\title{
Pure psychic akinesia with bilateral lesions of basal ganglia
}

\author{
DOMINIQUE LAPLANE, MICHEL BAULAC, DANIEL WIDLÖCHER, BRUNO DUBOIS
}

Hôpital de la Salpétrière, Paris, France

SUMMARY Three patients showed dramatic psychic akinesia after recovery from toxic encephalopathy. They had no or only mild motor disorders. The spontaneous psychic akinesia was reversible when the patient was stimulated, as if there was a loss of self psychic activation. Intellectual capacities were normal. Two patients had stereotyped behaviours resembling compulsions. In all patients CT cans showed bilateral lesions in the basal ganglia, mainly within the globus pallidus.

Mental disorders occur very frequently in basal ganglia diseases, such as Wilson's, Parkinson's, Hallervorden-Spatz diseases, Huntington chorea, and progressive supranuclear palsy ... The clinical picture of these mental disorders however, are extremely varied; they consist of psychiatric disorders, personality changes and often various degrees of intellectual deterioration, but this last feature can be absent. In spite of this diversity a peculiar clinical picture characterisation by slowing down of thought processes, inertia and memory disorders has been identified in several degenerative diseases, and has been described under the term of "subcortical dementia". ${ }^{2}$ Degenerative lesions are generally not limited to the basal ganglia, so eventual role in mental processes cannot be established. Contrarily, in the motor control field, there is much anatomical, physiological and clinical evidence (the two latter largely from the study of Parkinson's disease), leading to the conclusion that basal ganglia should be regarded as organs of motor control, as recently emphazised by Marsden. ${ }^{3}$

We have recently drawn attention to a psychic picture ${ }^{45}$ possibly the consequence of bilateral subcortical lesions in the basal ganglia, which was characterised by pure psychic akinesia without permanent dementia, and by pseudo-obsessional activities. We now report three similiar cases, which, in combination with some clinical and anatomical data in the literature, may furnish some support to

Address for reprint requests: Dr D Laplane, Hôpital de la Salpétrière, 47 Boulevard de l'Hôpital, 75651 Paris Cedex 13, France

Received 23 June 1983 and in revised form 10 October 1983 Accepted 14 October 1983 the hypothesis of a role played by the basal ganglia in mental processes.

\section{Case reports}

Case 1: In 1968, Mr V, a 41-year-old healthy man was stung on the left arm by a wasp. He immediately sustained a convulsive coma for 24 hours, then adopted intensive choreic movements (which were alleviated by thioproperazine), and impairment of gait. These extrapyramidal symptoms diminished over several months. Then, and during the twelve following years he appeared to be a mild dement, He was evaluated by us in 1980, and was at this time not receiving drugs. All his activities were dramatically reduced. He spent many days doing nothing, without initiative or motivation, but without getting bored. The patient described this state as "a blank in my mind". His affect was disturbed. When talking about family problems, sad or pleasant, he had an appropriate behaviour and gave signs of normal interest, but this attitude did not last and he became rapidly indifferent again. His fantasy life was poor, but dreaming was preserved. But when stimulated by external events, or more specially by another person he could perform quite correct complex tasks (for example, playing bridge). This fact was dramatically demonstrated by neuropsychological tests which showed intellectual capacities within the normal range (table).

Two years after the encephalopathy, he began to show stereotyped activities. The most frequent consisted in mental counting, for example, up to twelve or a multiple of twelve, but sometimes it was a more complex calculation. Such mental activities sometimes were accompanied by gestures, such as a finger pacing of the counts. To switch on and off a light for one hour or more was another of his most common compulsions. When asked about this behaviour he answered that he had to count ... that he could not stop it ... as that it was stronger than him .... Once he was found on his knees pushing a stone with the hands; he gave the explanation that he must push the 
Table

\begin{tabular}{|c|c|c|c|}
\hline & Patient 1 & Patient 2 & Patient 3 \\
\hline $\begin{array}{l}\text { Attention } \\
\text { orientation }\end{array}$ & $\begin{array}{l}\text { - correct orientation } \\
\text { - correct mental control (Wechsler } \\
\text { memory scale sub-tests: } 9 / 9) \\
\text { - forward digit span: five items. }\end{array}$ & $\begin{array}{l}\text { - correct orientation } \\
\text { - mental control correct (Wechsler } \\
\text { memory sub-test: } 9 / 9 \text { ) } \\
\text { - forward digit span: } 6 \text { items. }\end{array}$ & $\begin{array}{l}\text {-orientation to time and space } \\
\text { correct } \\
\text { - mental control (Wechsler } \\
\text { memory sub-test: } 4 / 9 \text { ) } \\
\text { - forward digit span limited to } \\
4 \text { items. }\end{array}$ \\
\hline $\begin{array}{l}\text { Specific } \\
\text { performances }\end{array}$ & $\begin{array}{l}\text { Poor spontaneous speech; reduced } \\
\text { fluency; correct naming; poor } \\
\text { evocation of animal names (12 in } \\
60 \text { seconds); story of Little Red } \\
\text { Riding Hood incomplete; correct } \\
\text { reading and spelling; handwriting } \\
\text { disorder; I.Q.: } 103 \text { on the } \\
\text { vocabulary test of Binois-Pichot } \\
\text { (6). Correct calculation. No } \\
\text { apraxia. Visuo-constructive } \\
\text { activities: correct explorations; } \\
\text { some blanks in the copy of Rey's } \\
\text { complex figure. }\end{array}$ & $\begin{array}{l}\text { Verbal fluency reduced, correct } \\
\text { naming, evocation of animal names } \\
\text { correct; correct reading and } \\
\text { spelling; correct handwriting. I.Q.: } \\
116 \text { on the vocabulary test of } \\
\text { Binois-Pichot. Correct calculation. } \\
\text { No apraxia. Visuo-constructive } \\
\text { activities: good copy of Rey's } \\
\text { complex figure. }\end{array}$ & $\begin{array}{l}\text { Language: the voice is low, fluency } \\
\text { is reduced and talking is poorly } \\
\text { informative. There is a lack of } \\
\text { words, handwriting is incorrect. } \\
\text { The patient could not perform the } \\
\text { vacabulary test of Binois-Pichot. It } \\
\text { must be kept in mind that the } \\
\text { patient is of Russian origin. } \\
\text { Calculation incorrect. No apraxia. } \\
\text { Visuo-constructive activities: } \\
\text { correct exploration; good } \\
\text { reproduction of Rey's complex } \\
\text { figure. }\end{array}$ \\
\hline $\begin{array}{l}\text { Intellectual } \\
\text { performances }\end{array}$ & $\begin{array}{l}\text { Wisconsin card sorting test: } 5 \text { clues } \\
\text { out of } 6 ; \text { I.Q.: } 114 \text { on the } \\
\text { Progressive Matrices Test (PM 38). } \\
\text { Difficulties in solving Luria's } \\
\text { problems (17). }\end{array}$ & $\begin{array}{l}\text { Wisconsin: } 4 \text { clues out of } 6 ; \text { I.Q.: } \\
99 \text { on the PM } 38 \text { test Luria's } \\
\text { problems: correct }\end{array}$ & $\begin{array}{l}\text { Failure in Wisconsin test. I.Q.: } 100 \\
\text { on the PM } 38 \text { test. }\end{array}$ \\
\hline Memory & $\begin{array}{l}\text {-retention and learning } \\
\text { insufficient (Wechsler memory } \\
\text { scale: } 88 \text { ) } \\
\text { - correct evocation of recent } \\
\text { events, remote memories, and } \\
\text { didactic learning. }\end{array}$ & $\begin{array}{l}\text {-retention and learning impaired } \\
\text { (Wechsler memory scale: } 70 \text { ) } \\
\text { - correct evocation of remote } \\
\text { learning. }\end{array}$ & $\begin{array}{l}\text {-insufficient results in retention } \\
\text { and learning (Wechsler memory } \\
\text { scale: } 97 \text { ) but correct evocation } \\
\text { of recent events and remote } \\
\text { memories. }\end{array}$ \\
\hline $\begin{array}{l}\text { Personality } \\
\text { evaluation }\end{array}$ & $\begin{array}{l}\text { Rorschach test: the test does not } \\
\text { show any indication of an } \\
\text { obsessional structuration; low self } \\
\text { control; there is however some } \\
\text { indication of an organic psycho- } \\
\text { syndrome. Minnesota Multiphasic } \\
\text { Personality Inventory (MMPI) } \\
\text {-normal profile; mild signs of } \\
\text { hysterical nature; depressive and } \\
\text { anxious elements are absent. The } \\
\text { personality is in the normal range, } \\
\text { albeit poor. }\end{array}$ & $\begin{array}{l}\text { Rorschach test: paucity of protocol, } \\
\text { numerous banalities and } \\
\text { stereotypes. } \\
\text { MMPI: normal pattern. }\end{array}$ & $\begin{array}{l}\text { Rorschach-answers are } \\
\text { qualitatively good and personality } \\
\text { seems to be well controlled. There } \\
\text { are probably some conflicts which } \\
\text { are underlined by difficulties in } \\
\text { sexual identification. There is no } \\
\text { depression. } \\
\text { MMPI: non valid. }\end{array}$ \\
\hline
\end{tabular}

stone, and he used the hands because he experienced some difficulties in skilled movements with his legs. There was however no anxiety, and in his past history there was no suggestion of an obsessional neurosis. Personality evaluation was normal (table).

Neurological examination showed abnormal movements. At the time of examination in 1980 choreic movements were very mild but voluntary movements were often brisk. He had a permanent facial rictus with some facial or mandibular movements somewhat resembling tics. With his finger movements it was difficult to distinguish between involuntary or "voluntary" activity associated with mental counting. Walking was a mixture of Parkinsonism and choreic disturbances.

Standard and sleeping EEG were normal, CT scans were performed in the orbito-meatal plane. Slices were taken every 3 millimeters in the basal ganglia area. An evaluation of lesion sites was made as precisely as possible after CT scan film magnification to real dimensions, by comparison with an atlas. ${ }^{7}$ The main lesions consisted of low density areas situated bilaterally in the internal part of the lentiform nucleus (fig 1). The rostral part of the nucleus seemed to be more affected than its caudal part. Some other small low density areas could be seen within the rostral right putamen and the head of the right caudate nucleus. No enhancement was noticed after contrast infusion. Mild ventricular enlargement was present.

Several drugs were systematically tried. Dopaminergic agents (agonist and antagonist), serotoninergic, cholinergic, noradrenergic and benzodiazepines were used. Most of this drugs had no or mild effects on the patient's symptomatology. Then, clomipramine was given up to 250 $\mathrm{mg} /$ day (under cardiovascular supervision) and this drug induced a dramatic improvement. For the first time for twelve years the patient was able to take the inititative to drive a car, and to initiate talking. Speech fluency reduction and stereotyped activities, however, remained.

The patient died suddenly from massive inhalation of food. Necropsy was not performed.

Case 2: Mr D was 23-years-old when he sustained in November 1979 carbon monoxide poisoning confirmed by blood level measurement $(3.2 \mathrm{~mm} \%)$. He was examined for the first time by us in January 1980 . Neurological examination was normal except for intellectual perfor- 

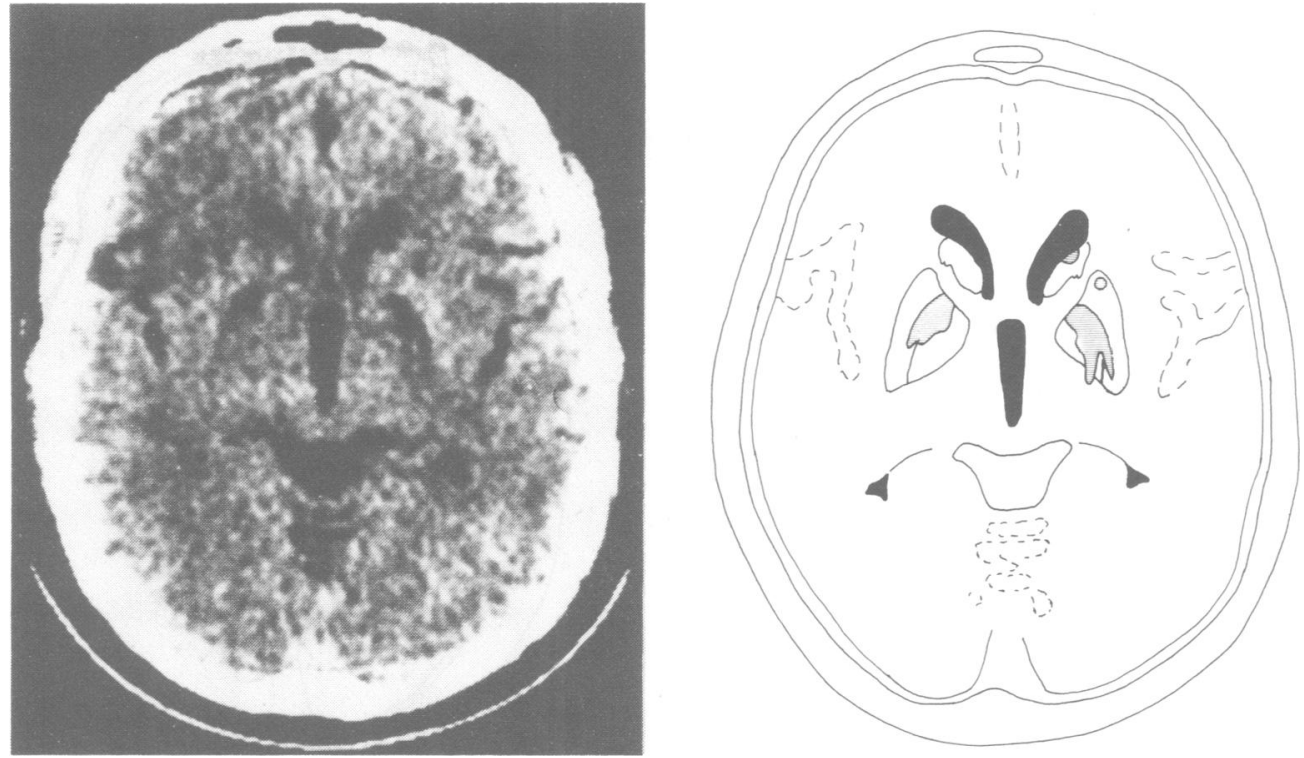

Fig 1 Case 1: CT scan, $42 \mathrm{~mm}$ above the orbito-meatal plane and schematic representation.

mance; memory and verbal fluency seemed deeply disturbed. The patient was examined again one year later. He had still severe disorders of memory and verbal fluency. However, intellectual performances were dramatically improved. He could perform complex tasks correctly and solve problems. But these faculties were largely underused. In the absence of external stimulation he lay for hours, eyes open, doing nothing. The contrast between his intellectual capacities and this inactivity was obvious in all aspects of his life. He talked only if asked, he took part in sport (he was a sports coach) only if stimulated by his wife, he went to visit friends only if invited by a phone call, and so on. His only spontaneous activity was of a routine nature like going out and getting the newspaper. His affect was impaired in the same way. If asked about the recent death of someone he cared about he cried sincerely, but if asked about recent events of his life he forgot the death and talked only about some political news. Stereotyped activities were not reported spontaneously by the patient, nor by his wife. But when questioned on this point, he admitted counting when he was alone with nothing to do; he counted from 1 to 20 again. To stop it he had to go out, or watch TV. This purely mental activity did not give him anxiety nor did its withdrawal. Besides this activity, there was no sign of an obsessional neurosis. Neurological examination was normal. Neuropsychological evaluation showed no deterioration except for a memory disorder (table).

EEG was normal. CT scan (orbito-meatal plane, slice thickness 10 millimeters) showed two low density areas almost symetrically placed in the internal part of the lentiform nucleus (fig 2). These low density areas were visible on one slice only. There were no other abnormalities.

Case 3: $\mathrm{Mr} \mathrm{P}$ born in Russia in 1911 and living in France since 1933, suffered in March 1970 carbon monoxide poisoning. There was a short coma followed by several days of headache and confusion. This man, whose profession was that of an artistic painter but who also did the job of messenger, was unable to re-start his work. He attended for neurologic consultation in April 1970, after being fired from his job because he was too slow. He had a "marche à petits pas", a resting tremor, an extrapyramidal rigidity predominant on the left side. Akinesia was obvious and verbal fluency was markedly reduced. Intellectual processes were slow and the whole picture tended to give the impression of mental deterioration. He was, however, able to perform complex tasks on request. He was institutionalised and his status improved during the first year, both in the extrapyramidal syndrome as well as in intellectual performances. At first unable on admission to conceive and execute basic drawings, one year later he could produce elaborate and artistic drawings and paintings. The most striking feature lay in his dramatic passivity, his lack of initiative despite the fact that his motor and mental capacities were largely preserved. He stayed in a ward, spending most of the time doing nothing and he never attempted to leave hospital. If questioned on this point, he answered that he didn't know, or that an authorisation to leave was required, that he had no family . . . anyway, he didn't feel bored. His lack of initiative was, however, not total since he had some spontaneous activities, such as helping the other patients in eating and shaving, and sometimes he watched TV, or read the newspaper. He went out to walk in the park only if he had been actively encouraged. He was able to perform artistic paintings; but for years he painted the same landscape of moors and fens, and this several dozens of times. His affect was poor in relation to his solitude-when questioned about his biography, he evoked spontaneously with sadness the death of his mother or brother. 

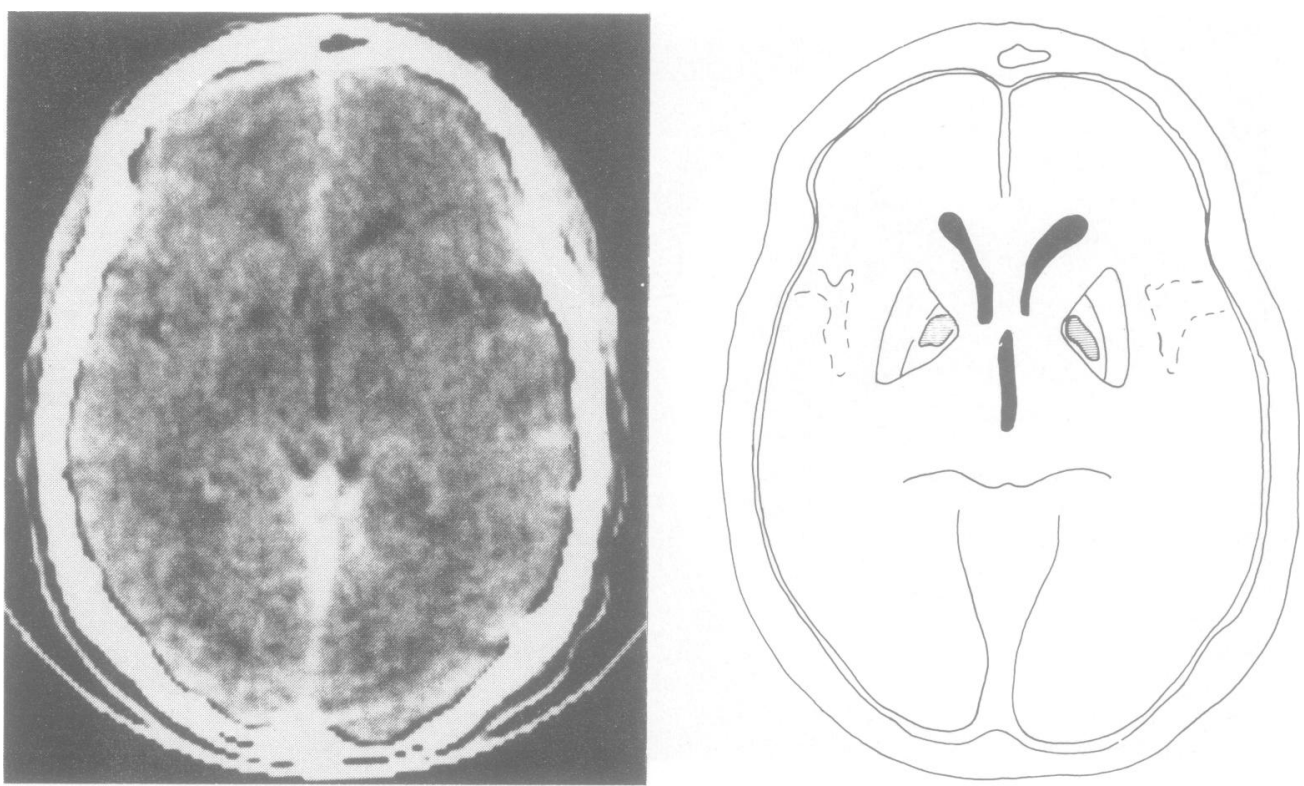

Fig 2 Case 2: CT scan $40 \mathrm{~mm}$ above the orbito-meatal plane and schematic representation.

Neurological examination was normal. A mild motor akinesia was noticed. Neuropsychological evaluation is shown in the table. Language disorders were present, some of them due to the Russian origin of the patient.

The EEG was within normal limits. CT scan (orbitomeatal plane, slice thickness $10 \mathrm{~mm}$ ) showed two bilateral abnormal areas with spontaneous high density, which cor-

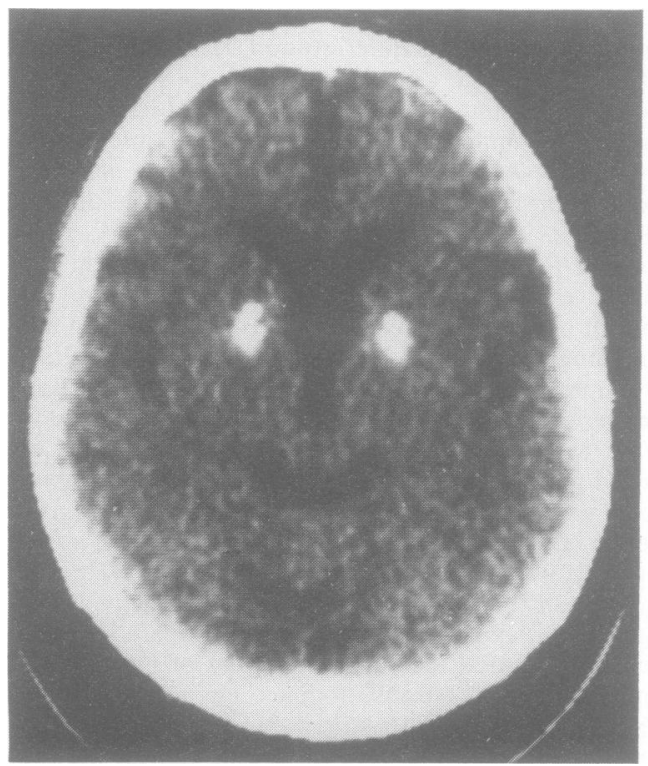

responded to calcified lesions (fig 3 ) in the internal part of the lentiform nucleus. There was no other calcification. There was some degree of cortical sulci widening and of ventricular enlargement. Contrast medium infusion showed no enhancement. Laboratory data, including serum calcium phosphorus and parathyroid hormone levels were within the normal range.

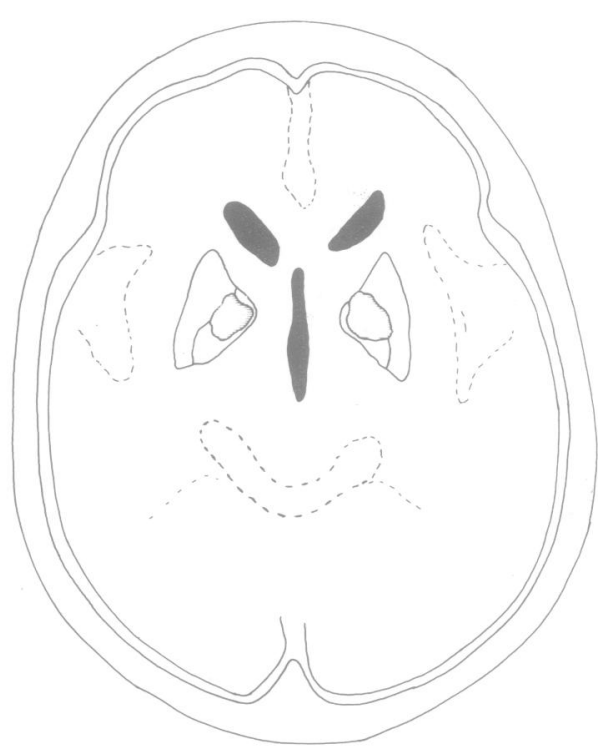

Fig 3 Case 3: CT scan $45 \mathrm{~mm}$ above the orbito-meatal plane and schematic representation. 
Discussion

\section{PSYCHIC AKINESIA}

The main disorder in our three patients was a spontaneous psychic akinesia, which led to a severe reduction of both mental and behavioural activities. Unlike patients with diseases which induce psychic and "motor" akinesia such as Parkinson disease, our patients had no reduction of their motor ability. Their normal or largely preserved intellectual capacities stood in contrast to their spontaneous psychic inertia. This was especially evident during neuropsychologic testing. The other symptoms of our patients were a defect in speech fluency, memory disorder (case 2 and 3 ), a decrease in affect and stereotyped activities (case 1 and 3 ). The psychic akinesia was less severe in case 3 .

As shown by neuropsychologic assessment, there was no aphasia, apraxia, nor agnosia. Somewhat similar pictures have been described ${ }^{\prime 2}$ as subcortical dementia in neurological diseases such as progressive supranuclear palsy, Parkinson disease, Huntington's chorea. This terminology does not imply, however, that any cortical involvement is absent, but that lesions presumably predominate at subcortical and basal ganglia level. Indeed the psychic disorder often encountered in progressive supranuclear palsy is similar to that of our patients. According to Albert et al's description, 'it includes: (1) memory disorder, (2) slowing of thought processes, (3) personality changes with inertia and apathy, (4) impaired ability to manipulate acquired knowledge. The neuropathological changes of progressive supranuclear palsy affect primarily the upper brain stem, but they frequently also involve the basal ganglia, and especially the pallidum. ${ }^{8}$

In Parkinson's disease the mental disorders have been widely investigated. They consist mainly of depression, a variable degree of impairment of intellectual function, personality changes, with sometimes a slowing down of mental process. ${ }^{29}$ This slowing down of thoughts has been described in the literature under various names, such as bradyphrenia, ${ }^{10}$ mental viscosity, ${ }^{11}$ or psychic akinesia. ${ }^{12}$ This state was described as follows by Mettler ${ }^{13}$... "with hypokinesia and rigidity appear a slowed reaction time, a loss of mental speed and agility, a certain deliberateness and indecision or suspension of decision, without any real evidence of impairment of intellectual capacity". However reversibility of psychic akinesia by external stimulation was not noticed. Though some demented Parkinsonian subjects may have cortical lesions, it has been shown that the slowing down of mental processes was best correlated with subcortical dysfunction. ${ }^{14}$ Similar psychic akinesia was also described in post encephalitic Parkinsonism, ${ }^{15}$ where cortical involvement is usually small. ${ }^{16}$ But in Parkinsonism, as in progressive supranuclear palsy there is an obvious reduction of motor abilities, in contradistinction with our patients who had no or only mild extrapyramidal symptoms and thus displayed a pure psychic akinesia. Such descriptions of pure psychic akinesia, reversible under external stimulation, are rare in the literature. They are however mentioned as pure mental sequellae of encephalitis lethargica (Bleuler personal communication, and Naville). ${ }^{10}$ This latter author gave the following description: "these patients if they are not stimulated at every moment stay doing nothing as if they have lost their psychic tone. ... This syndrome may be reversible by an external stimulus as if it was able to compensate for the lack of internal stimuli". Unfortunately no pathological data are available in such observations. It can be noticed however that in sequellae of encephalitis lethargica, the usual lesions are primarily located in brain stem, basal ganglia including pallidum, the cortical changes being generally moderated or absent. ${ }^{16}$

From another point of view there are some similar features in the clinical picture of our patients and symptoms of an impairment of frontal lobe activity. Patients with frontal lobe lesions also display a slowing down of thoughts, a decrease in behavioural activities, apathy, indifference. ${ }^{17}$ These similarities between subcortical dementia and frontal lobe syndrome were pointed out by Albert. ${ }^{2}$ This comparison is also supported by experimental studies in the monkey which showed that lesions of the head of the caudate nucleus can induce behavioural disturbances very similar to those induced by a prefrontal lesion. ${ }^{18}$ As far as our cases are concerned there are however strong differences, since when stimulated our patients were able to have and to maintain normal intellectual activities or behavioural programmes, whereas the maintenance of attention upon a task is very difficult in patients with frontal lobe syndromes.

This reversibility of the psychic akinesia under stimulation was so dramatic in our patients that it is not possible to apply the term of dementia to them. Besides mnesic impariment (cases 2 and 3) they had no permanent disorder of specific intellectual function. It appears as a loss of psychic self-activation concerning all mental activities, cognitive and affective including fantasmatic life. This defect in spontaneous internal activation could be compensated for by external stimulation. Some psychiatric conditions also present a more or less reversible psychic akinesia, such as hebephrenia or some depressive states. 
COMPULSIVE-LIKE ACTIVITY

The existence of stereotyped behaviour in patients 1 and 2 represents another dramatic aspect of these cases. They consisted mainly of a counting activity, purely mental or paced by finger movement. In patient 1 they could occupy all the time he spent alone, unstimulated. These activities may be interpreted as compensating activities which invade an empty, aimless mind, deprived of more elaborate purposes. Such an interpretation is in agreement with the dynamic theory of Janet ${ }^{19}$ who described repetitive activities as the lower level of psychic life, due to a decrease in "tension psychologique".

In several aspects this repetitive behaviour strongly resembled compulsive acts. Patient 1 , when questioned on his activities answered that he had to do so; when counting he had to reach some magic numbers or multiples of these numbers; the second patient made attempts to withdraw himself from these behaviours by focusing his attention upon TV or a newspaper. However in spite of the compulsive appearance of these activities and some struggle against them, patients did not feel any anxiety when they tried to withdraw. In their daily life they did not show any anxious thought, or permanent doubt such as that showed by obsessional subjects. Nothing either in their histories or in the recent assessment of their personality suggested an obsessional neurosis.

It is of interest that in some neurological diseases obsessive-compulsive behaviour has been reported and that they were thought possibly to be due to basal ganglia impairment. In numerous cases of Parkinsonism, ${ }^{152-24}$ most of them being postencephalitic cases, ${ }^{15}$ obsessive-compulsive activities were described such as arithmomania, vocalisations, or purely obsessional thoughts. These behaviours often occurred in short crises lasting some minutes and could be accompanied by motor disorders such as oculocephalogyric fits and by personality changes such as emotion-aggressivity but mainly anxiety. Some cases, ${ }^{20}$ however, are very similar to our patients, since obsession-compulsions are described as occurring without modifications of the emotional state, as a substitution phenomenon triggered by an inner blocking of thoughts. The association of obsessioncompulsions and tics can be present in Gilles de la Tourette syndrome. An organic background at the basal ganglia level has been suspected in this disease on the basis of anatomical, ${ }^{25}$ clinical and pharmacological findings. ${ }^{26}$

THE ROLE OF PALLIDAL LESION

On CT scan of the three patients lesions were present in the deep forebrain at the basal ganglia level. In the following discussion, we do not imply that our patients had no other brain lesions, such as in the cerebral cortex, but we think that there is some reason to suggest that these basal ganglia lesions play the most important role in the mental symptomatology: (1) the lesions are presumed to be located in the pallidal area and the patients suffered from diseases known to determine lesions in that area. (2) several data in literature suggest or demonstrate that pallidal lesions may be followed by mental changes resembling to psychic akinesia.

CT scan analysis by magnification and comparison with an atlas ${ }^{7}$ suggest that the bilateral lucencies were located in the internal part of the lentiform nucleus, that is the pallidal area. This precise site of lesion is frequently observed on neuropathological examination of brain from subjects who died from carbon monoxide intoxication. ${ }^{27-29}$ It is thus widely assumed that the bilateral lucencies discovered on CT scan in the same aetiology are actually located in the globus pallidus. ${ }^{30-34}$ Lesions in case 1 seem to be more lateral, presumably overlapping the putamen. Necrotic lesions with this localisation have been reported in wasp sting encephalopathy from pathological material. ${ }^{35}$ In both diseases, however, the white matter and/or cerebral cortex can be involved but, if it was present in our patients, such damage was too subtle to be seen on CT scan.

As previously outlined several diseases which include a pallidal impairment can give a psychic akinesia, that is progressive supranuclear palsy, Parkinson's disease sequellae of encephalitis lethargica. More interestingly bilateral subcortical lesions performed for the management of some Parkinsonian symptoms have induced psychological changes somewhat similar to our patients' disturbances. ${ }^{36} 37$ It is sometimes difficult to get a clear picture of the effects of bilateral operations, as several reports do not distinguish between pallidal and thalamic lesions on one hand and between unilateral and bilateral lesions on the other hand. It appears however that the mental changes are more pronounced when the pallidum is involved. Unilateral pallidal lesion may induce transient changes, ${ }^{37}$ but bilateral pallidal lesions, or pallidal and controlateral thalamic lesions, can induce more durable changes. ${ }^{38}{ }^{39}$ These changes are described as inertia, lack of drive, decrease of emotional-motivational behaviour ${ }^{37}$ or as a psycho-organic syndrome with sometimes compulsory activities. ${ }^{39}$ They are summarised by Ricklan and Levita ${ }^{37}$ as a non specific decline in the maintenance of energy level and initiative which contrasts with the lack of changes on specific tests. Speech impairment is often reported. These symptoms seem to be less severe than in our patients, but stereotaxic lesions are usually small, affecting only a part of the globus pallidus. On the contrary, however, a case of 
almost total reduction of psychic and motor activities is reported after such bilateral surgery with post mortem anatomical study which showed large bilateral pallidal lesions. ${ }^{40}$

Further support for a role of pallidum in psychic processes can be obtained from the study of its connections. Several connections have been established between the globus pallidus and some brain areas which are not acknowledged as motor structures. On the input side, it has been demonstrated in the mon$k e y^{4142}$ that the rostral part of globus pallidus receives afferents from rostral and medial parts of neostriatum. The rostral neostriatum receives predominantly, though not exclusively, fibres from prefrontal cortex ${ }^{43-45}$ This was also suggested by behavioural studies from Rosvold. ${ }^{18}$ It is thus possible that in the monkey and in man some part of the globus pallidus and rostral neostriatum functions primarily with the prefrontal cortex, as was shown in the rat. ${ }^{46}$ This fact can account for an anatomical basis for similarities between some aspect of subcortical dementia and frontal syndromes. Moreover, in the rat, a strong limbic imput (from amygdala and hippocampus) has been demonstrated on the rostral neostriatum. ${ }^{4748}$

The efferent pallidal fibres which leave the basal ganglia arise from the medial segment of globus pallidus. A large "motor" outflow is directed toward the ventral lateral-ventral anterior thalamic complex. But this medial segment of GP sends also efferents toward intralaminar thalamic nuclei and then to diffuse areas of neocortex, toward the brain stem and toward the habenular nuclei. ${ }^{49-52}$

It has been suggested from investigations in the rat $^{53}$ that fibres destined for the habenula arise primarily from the rostral half of the entopedoncular nucleus - the rat's equivalent of medial globus pallidus and that this part of the nucleus might be termed the "limbic pallidum". The pallidal organisation in its output elements seems more complex in primates. $^{5455} \mathrm{~A}$ central zone can be described where most neurons send axonal branches to both the thalamus and the mid-brain, and a peripheral limbic zone which encroaches upon lateral hypothalamus and whose cells project only to the habenula. These projections may be of great significance since they mean that the striatal efferents mediated by the medial globus pallidus have limbic interrelations. If these habenular connections are dense in animals, their importance remains however to be determined in man.

Besides the heterogeneity of its connectivity the globus pallidus proper is crossed or bordered by several systems of fibres in passage, and is embedded in a peripallidal area which contains functionally different cells. The extension of the lesions to the peripallidal area cannot be accurately established from CT scans in our patients, but such a possibility has to be taken in account. Thus several other hypothesis may be formulated, as contributing to the generation of the mental symptoms: (1) slight encroachement upon the anterior limb of the internal capsule (2) involvement of the ventral extension of the pallidum within the substantia innominata, the functions of this recently described ventral pallidum remaining largely unsettled. ${ }^{56}$ (3) Interruption of ascending fibre bundles especially the cathecholaminergic pathways which run in the vicinity of globus pallidus ${ }^{57}$ (4) lesion of the cholinergic cell clusters, such as the basal nucleus of Meynert which lie just beneath the globus pallidus. ${ }^{58} 59$ These cells are responsible for the extrinsic cholinergic innervation of the neocortex and their degeneration is currently the subject of a great research interest since it occurs in Alzheimer dementia (see for review ref 60 ). However the clinical consequences of impairment of these cells remain unknown.

Such a complexity of the pallidal area helps to explain the complexity of the clinical manifestations which can be observed in the case of lesions in this site (see ref 61 for detailed review). It is somewhat surprising that damage to this area can induce diversified motor disorders such as rigidity, dystonia, ${ }^{61}{ }^{62}$ postural disturbance ${ }^{63}$ or pure Parkinsonism. ${ }^{27}{ }^{34}$ The simultaneous occurrence of motor and psychic impairment is not expressely mentioned in the literature concerned with the consequences of pallidal damage. ${ }^{61}$ It seems conceivable, however, that psychic akinesia may be present in some cases, but may be very difficult to discern when speech and gesture are severely impaired. Finally pallidal damage can exist without neuropsychological symptoms. ${ }^{61}$ The possibility of pure motor disorders and conversely of pure psychic disorders as in the present cases, suggests that the lesions may not involve equally the different anatomical systems located in the pallidal area. Furthermore a disorder in this area should be considered in research on several psychiatric conditions, such as hebephrenia, obsessional neurosis or severe depression.

\section{References}

${ }^{1}$ Albert ML, Feldman RG, Willis AL. The "subcortical dementia" of progressive supranuclear palsy. J Neurol Neurosurg Psychiatry 1974;37:121-30.

${ }^{2}$ Albert ML. Subcortical dementia. In: Katzman R, Terry RD, Bick Kl, eds. Alzheimer's Disease: Senile Dementia and Related Disorders. Aging, Vol 7. New York: Raven Press 1978;173-80.

${ }^{3}$ Marsden CD. The mysterious motor function of the basal ganglia: The Robert Wartenberg lecture. Neurology (NY) 1982;32:514-39. 
${ }^{4}$ Laplane D, Widlocher D, Pillon B, Baulac M, Binoux F. Comportement compulsif d'allure obsessionnelle par nécrose circonscrite bilatérale pallido-striatale. Encephalopathie par piqure de guêpe. Rev Neurol (Paris) 1981;137:269-76.

${ }^{5}$ Laplane D, Baulac M, Pillon B, PanayotopoulouAchimestos I. Perte de l'autoactivation psychique. Activité compulsive d'allure obsessionnelle. Lésion lenticulaire bilatérale. Rev Neurol (Paris) 1982;138: 137-41.

${ }^{6}$ Binois R, Pichot P. Test de Vocabulaire. Paris: Les Editions du Centre de Psychologie Appliquée 1958.

${ }^{7}$ Salamon G, Huang YP. Computed Tomography of the Brain. Heidelberg: Springer Verlag, 1980.

${ }^{8}$ Steele JC, Richardson JC, Olszewski J. Progressive supranuclear palsy. Arch Neurol 1964;10:333-59.

${ }^{9}$ Mayeux R, Stern Y, Rosen I, Levanthal J. Depression, intellectual impairment, and Parkinson disease. Neurology (NY) 1981;31:645-50.

${ }^{10}$ Naville F. Etude sur les complications et les séquelles mentales de l'encéphalite épidémique. La bradyphrénie. Encephale 1922;17:369-36.

"Verger H, Hesnard A. Recherches physiopathologiques sur la bradykinesie post encephalituque (syndrome de viscosité motrice). Encephale 1922;17:409-23.

${ }^{12}$ Hassler R. Extrapyramidal-motorische systeme und erkrankungen-Handbuch der Inneren Medizin. 4th ed. Vol. V/3. Berlin-Göttingen, Heidelberg: Springer Verlag 1953;676-904.

${ }^{13}$ Mettler FA. The experimental anatomophysiologic approach to the study of diseases of the basal ganglia. J Neuropath Exp Neurol 1955;14:115-41.

${ }^{14}$ Mortimer JA, Pirozzolo FJ, Hansch EC, Webster DD. Relationship of motor symptoms to intellectual deficits in Parkinson disease. Neurology (NY) 1982;32: 133-7.

is De Ajuraguerra J. Etude psychopathologique des parkinsoniens. In: De Ajuriaguerra J, Gauthier G., eds. Monoamines, noyaux gris centraux et syndromes parkinsoniens. Paris: Masson 1971:327-51.

${ }^{16}$ Hirano A, Zimmerman HM. Alzheimer's neurofibrillary changes. Arch Neurol 1962;7:227-42.

${ }^{17}$ Luria AR. Higher cortical functions in man. New York: Basic Books 1966.

${ }^{18}$ Rosvold HE. The frontal lobe system: corticosubcortical interrelationships. Acta Neurobiol Exp 1972;32:439-60.

19 Janet P. Les obsessions et la psychasthénie. Paris: Félix Alcan 1919.

${ }^{20}$ Jelliffe SF. Psychologic components in postencephalitic oculogyric crises. Arch Neurol Psychiat 1929;21:491-532.

${ }^{21}$ Schilder P. The organic background of obsessions and compulsions. Am J Psychiatry 1938;94:1397-1416.

${ }^{22}$ Rosner AA. Unit reaction states in oculogyric crises. Am J Psychiatry 1942;99:224-8.

${ }^{23}$ Schwab RS, Fabing HD, Prichard JS. Psychiatric symptoms and syndromes in Parkinsonian disease. Am J Psychiatry 1951;107:901-7.

${ }^{24}$ Mindham RHS. Psychiatric symptoms in Parkinsonism. $J$ Neurol Neurosurg Psychiatry 1970;33:188-91.

${ }^{25}$ Balthazar $K$. Uber das anatomische substrat der generalisierten Tic-Krankheit (maladie des tics, Gilles de la Tourette): Entwicklungshemmung der corpus striatum. Arch Psychiat Nervenkr 1957;195:531-49.

${ }^{26}$ Shapiro AK, Shapiro ES, Bruun ED, Sweet RD. Gilles de la Tourette Syndrome. New York: Raven 1978.

${ }^{27}$ Grinker R. Parkinsonism following carbon monoxide poisoning. J Nerv Ment Dis 1926;64:18-28.

${ }^{28}$ Richardson JC, Chambers RA, Heywood PM. Encephalopathies of anoxia and hypoglycemia. Arch Neurol 1959;1:70-92.

${ }^{29}$ Lapresle J, Fardeau M. Anatomical study of brain lesions following intoxication with carbon monoxide (22 cases). In: Bour H, Ledingham I MCA, eds. The Central Nervous System and Carbon Monoxide Poisoning. Progress in Brain Research. Amsterdam: Elsevier 1967;24:31-74.

${ }^{30}$ Nardizzi LR. Computerized tomographic correlate of carbon monoxide poisoning. Arch Neurol 1979;36:38-39.

${ }^{31}$ Illum F. Calcification of the basal ganglia following carbon monoxide poisoning. Neuroradiology 1980;19:213-4.

${ }^{32}$ Kim KS, Weinberg PE, Suh JH, Ho SU. Acute carbon monoxide poisoning: computed tomography of the brain. Am J Neuroradiology 1980;1:399-402.

${ }^{33}$ Sawa GM, Watson CPN, Terrbrugge K, Chiu M. Delayed encephalopathy following carbon monoxide intoxication. Can J Neurol Sci 1981;8:77-79.

${ }^{34}$ Klawans HL, Stein RW, Tanner CM, Goetz CC. A pure parkinsonian syndrome following acute carbon monoxide intoxication. Arch Neurol 1982;39:302-304.

${ }^{35}$ Castaigne P, Bertrand I, Buge A, Godet-Guillain J, Escourolle R, Martin M. Coma prolongé secondaire à une piqure d'insecte. Nécrose symétrique des putamens, ramollissement cortical étendu. Rev Neurol (Paris) 1962;107:401-16.

${ }^{36}$ Selby G. Stereotactic surgery for the relief of Parkinson's disease. Part 1. A critical review. J Neurol Sci 1967;5:315-42.

${ }^{37}$ Riklan M, Levita E. Subcortical Correlates of Human behavior. Williams and Wilkins: Baltimore, 1969.

${ }^{38}$ Gillingham FJ, Kalyanaraman S, Donaldson AA. Bilateral stereotaxic lesions in the management of parkinsonism and the dyskinesias. $\mathrm{Br} \mathrm{Med} J$ 1964;2:656-9.

${ }^{39}$ Krayenbühl H, Wyass OAM, Yasargil MG. Bilateral thalamotomy and pallidotomy as treatment for bilateral Parkinsonism. J Neurosurg 1961;18:429-444.

${ }^{40}$ Hassler R. Brain mechansims of intention and attention with introductory remarks on other volitional processes. In: Kornhüber HH, Deeke L eds. Progress in Brain Research, Amsterdam, Elsevier, 1980;54:585614.

${ }^{41}$ Szabo J. Topical distribution of the striatal efferents in the monkey. Exp Neurol 1962;5:21-36.

${ }^{42}$ Grofova I. Extrinsic connections of the neostriatum. In: Divac I. Oberg RGE, eds. The neostriatum. Oxford: Pergamon Press 1979:37-51.

${ }^{43}$ Kemp JM, Powell TPS. The cortico-striate projection in the monkey. Brain 1970;93:525-546.

${ }^{44}$ Goldman PS, Nauta WJH. An intricately patterned prefronto caudate projection in the rhesus monkey. $J$ Comp Neurol 1977;171:369-86. 
45 Yeterian EH, Van Hoesen GW. Corticostriate projections in the rhesus monkey: the organization of certain cortico-caudate connections. Brain Res 1978;139:43-63.

${ }^{46}$ Divac I, Diemer NH. Prefrontal system in the rat visualized by means of labeled deoxyglucose. Further evidence for functional heterogeneity of the neostriatum. J Comp Neurol 1980;190:1-13.

${ }^{47}$ Kelley AE, Domesick VB, Nauta WJ. The amygdalostriatal projection in the rat-an anatomical study by anterograde and retrograde tracing methods. Neuroscience 1982;7:615-30.

${ }^{48}$ Kelley AE, Domesick VB. The distribution of the projection from the hippocampal formation to the nucleus accumbens in the rat: an anterograde and retrograde horseradish peroxidase study. Neuroscience 1982;7:2321-35.

${ }^{49}$ Nauta WJH, Mehler WR. Projections of the lentiform nucleus in the monkey. Brain Res 1966;1:3-42.

${ }^{50} \mathrm{Kuo} \mathrm{JJ}$, Carpenter MB. Organization of pallidothalamic projections in the rhesus monkey. J Comp Neurol 1973;151:201-36.

${ }^{51}$ Kim R, Nakano K, Jayaraman A, Carpenter MB. Projections of the globus pallidus and adjacent structures: An autoradiographic study in the monkey. J Comp Neurol 1976; 169:263-90.

52 De Vito JL, Anderson ME. An autoradiographic study of afferent connections of the globus pallidus in Macaca mulatta. Exp Brain Res 1982;46:107-117.

${ }^{53}$ Van der Koy D, Carter DA. The organization of the afferent projections and striatal afferents of the entopeduncular nucleus and adjacent areas in the rat. Brain Res 1981;211:15-36.
${ }^{54}$ Parent A. Identification of the pallidal and peripallidal cells projecting to the habenula in monkey. Neurosci Lett 1979;15:159-64.

ss Parent A, De Bellefeuille L. Organization of the efferent projections from the internal segment of globus pallidus in primate as revealed by fluorescence retrograde labelling method. Brain Res 1982;245:201-13.

${ }^{56}$ Schwitzer RC, Hill J, Heimer L. The globus pallidus and its rostroventral extension into olfactory tubercle of the rat: a cyto and chenoarchitectural study. Neuroscience 1982;7:1891-904.

57 Nobin A, Björklund A. Topography of the monoamine neuron systems in the human brain as revealed in fetuses. Acta Physiol Scand 1973; Suppl 388:1-40.

${ }^{58}$ Kievit J, Kuypers HGJM. Basal forebrain and hypothalamic connections to the frontal cortex and parietal cortex in the rhesus monkey. Science 1975; 187:660-2.

${ }^{59}$ Fibiger HC. The organization and some projections of cholinergic neurons of the mammalian forebrain. Brain Res Rev 1982;4:327-88.

${ }^{60}$ Coyle JT, price DL, Delong MR. Alzheimer's disease. A disorder of cortical cholinergic innervation. Science 1983;219:1184-90.

${ }^{61}$ Jellinger K. Degeneration and exogenous lesions of the pallidum and striatum. In: Vinken PJ Bruyn GW, eds. Handbook of clinical Neurology. Amsterdam North Holland 1968;6:632-703.

${ }_{62}$ Van Bogaert L. Aspects cliniques et pathologiques des atrophies pallidales et pallido-luysiennes progressives. J Neurol Neurosurg Psychiatry 1946;9:125-57.

${ }^{63}$ Martin JP. The Globus Pallidus in post-encephalitic parkinsonism. J Neurol Sci 1965;2:344-65. 